\title{
Effect of L-Carnitine Supplementation on Boar Semen Quality
}

\author{
E. JACYNO ${ }^{1}$, A.KOŁODZIEJ ${ }^{1}$, M. KAMYCZEK ${ }^{2}$, M. KAWĘCKA ${ }^{1}$, K. DZIADEK ${ }^{2}$, A. PIETRUSZKA ${ }^{1}$ \\ ${ }^{1}$ Department of Pig Breeding, University of Agriculture, Szczecin, Poland \\ ${ }^{2}$ National Research Institute of Animal Production, Kraków, Poland
}

\author{
Received February 2, 2006 \\ Accepted October 2, 2007
}

\begin{abstract}
Jacyno E., A. Kołodziej, M. Kamyczek, M. Kawęcka, K. Dziadek, A. Pietruszka: Effect of L-Carnitine Supplementation on Boar Semen Quality. Acta Vet Brno 2007, 76: 595-600.

The effect of addition of L-carnitine on boar semen quality was studied in 5 Pietrain boars at age $1.5-2.0$ years. The boars received $500 \mathrm{mg}$ of L-carnitine per day for 5 weeks. During this period, their ejaculates were collected once a week and evaluated for quality. The control ejaculates had been collected before the application of L-carnitine. It was found that the addition of L-carnitine to the boars' feed had a positive effect on the quality of boar semen. The total ejaculate volume and sperm-rich fraction volume increased by $11 \%$ and $10 \%$, respectively; the total ejaculate sperm count increased by $11.5 \%(P<0.05)$. Also, the number of spermatozoa with major and minor morphological changes decreased and seminal plasma activity of AspAT was significantly reduced $(P<0.01)$. Sperm concentration and motility, as well as normal acrosome sperm percentage, did not increase considerably. The positive effect of L-carnitine on boar semen quality was observable as early as after one week of its application.
\end{abstract}

L-carnitine, boars, semen, spermatozoa, seminar plasma, AspAT

Carnitine occurs in the form of L-and D-isomers; however, only the L-isomer of carnitine is biologically active, while the D-isomer may even be noxious for the organism (Szilagyi 1998). L-carnitine is a natural, vitamin-like amino-acid, synthesised within the body from lysine and methionine (Vaz et al. 2002), and is very important in the metabolism of lipids. It carries long-chain fatty acids to the mitochondria for beta-oxidation, which produces energy (ATP) needed by the cells for proper functioning (Hoppel 2003; Ramsay et al. 2001).

L-carnitine plays an important role in the processes of cellular detoxification, since it removes acyl-CoA from the mitochondria, excess of which has a toxic effect (ArrigoniMartelli and Caso 2001). It also protects cellular membranes against oxidative damages resulting from peroxidation of polyunsaturated fatty acids that are a component of membrane phospholipids (Kalaiselvi and Panneerselvam 1998).

We can find scant information in literature regarding the positive effect that L-carnitine exerts on male reproductive processes, especially on spermatogenesis. The compound increases sperm concentration and motility in men with idiopathic asthenozoospermia (Vitali et al. 1995; Matalliotakis and Koumantakis 2000), in adult male chickens (Neuman et al. 2002), and in rats (Palmero et al. 1990).

L-carnitine also has a positive effect on boar reproduction. Its concentration in epididymal plasma of the boars ranges between 200 - $300 \mathrm{nmol} \cdot \mathrm{mg}^{-1}$ of protein; from there, L-carnitine is transported by passive diffusion to the spermatozoa (Jeulin et al. 1987). An addition of L-carnitine in the ration increases its concentration in the epididymal tubules and, consequently, in the spermatozoa (Jeulin et al. 1994). Inside a sperm cell, L-carnitine transports fatty acids to the mitochondria, where they undergo beta-oxidation leading to the generation of metabolic energy needed by the sperm cells for their progressive movement (Jeulin et al. 1987).

Address for correspondence:

Prof. dr hab. Eugenia Jacyno

Department of Pig Breeding, University of Agriculture

Doktora Judyma 10 str., 71-460 Szczecin, Poland

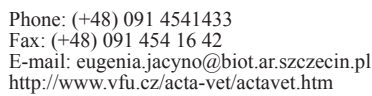

Phone: (+48) 0914541433

Fax: (+48) 0914541642

E-mail: eugenia.jacyno@biot.ar.szczecin.pl

http://www.vfu.cz/acta-vet/actavet.htm 
Boars receiving $500 \mathrm{mg}$ (Baumgartner 1998) or $230 \mathrm{mg}$ (Währner et al. 2004) of L-carnitine in their daily ration demonstrated increased ejaculate volume and sperm concentration. Other experiments (Kozink et al. 2004) have not proved that the addition of L-carnitine (500 $\mathrm{mg} \cdot$ day $\left.^{-1}\right)$ might affect young boar (eight months old) semen quality. The authors have proved only an increase of spermatozoa concentration in adult boars (one and a half years old).

Scarce literature data and ambiguous results reported by other authors encouraged us to undertake this study in order to establish the effect of L-carnitine added to the daily feed ration on the quality of boar semen.

\section{Materials and Methods}

Animals and feeding

The experiment was carried out on 5 Pietrain boars aged 1.5 and 2 years. The males were kept in individual pens $\left(6.75 \mathrm{~m}^{2}\right)$, floored partly in grid $(40 \%)$, each equipped with a waterer. Each boar had an outside run of $11 \mathrm{~m}^{2}$ in area. The animals were fed a diet (Table 1) prepared in the form of pellets and, additionally, for 5 weeks they received $500 \mathrm{mg}$ of L-carnitine (Carniking, Lonza Ltd, Warsaw, Poland) per boar per day. During the period of L-carnitine administration, semen was collected once a week. A total of 25 ejaculates were subjected to evaluation. Quality of semen collected from the same boars (10 ejaculates; 2 from each boar) before the experiment was used

Table 1. Chemical composition and nutritive value of complete mixture

\begin{tabular}{|l|c|}
\hline Specification & \\
\hline Ground wheat (\%) & 39 \\
Ground barley (\%) & 30 \\
Ground oat (\%) & 12 \\
Soyabean oilmeal 46\% protein (\%) & 15 \\
Premix (\%) & 3 \\
Colza oil (\%) & 1 \\
\hline In 1 kg mixture & \\
$\quad$ Metabolizable energy (MJ) $)^{2 /}$ & 12.70 \\
$\quad$ Crude protein (g) & 161 \\
$\quad$ Crude fibre (g) & 56 \\
$\quad$ Lysine (g) & 9.4 \\
$\quad$ Methionine+cystine (g) & 6.3 \\
Threonine (g) & 5.9 \\
Tryptophan (g) & 2.0 \\
Calcium (g) & 7.6 \\
Phosphorus (g) & 6.8 \\
Sodium (g) & 1.7 \\
Selenium (mg) & 0.40 \\
Vitamin A (IU) & 150 \\
Vitamin D3 (IU) & 980 \\
Vitamin E (mg) & \\
\hline
\end{tabular}

${ }^{1 / T h e ~ p r e m i x ~ s u p p l i e d ~ t h e ~ f o l l o w i n g ~ p e r ~} \mathrm{~kg}$ diet:

12000 IU vit.A, $1980 \mathrm{IU}$ vit. $\mathrm{D}_{3}, 150 \mathrm{mg}$ vit.E, 2.25 $\mathrm{mg}$ vit. $\mathrm{K}_{3}, 1.8 \mathrm{mg}$ vit. $\mathrm{B}_{1}, 3.9 \mathrm{mg}$ vit. $\mathrm{B}_{2}, 2.25 \mathrm{mg}$ vit. $\mathrm{B}_{6}$, $0.024 \mathrm{mg}$ vit. $B_{1,2}, 27 \mathrm{mg}$ nicotinic acid, $12.9 \mathrm{mg}$ calcium pantothenate, $0.9 \mathrm{mg}$ folic acid, $0.54 \mathrm{mg}$ biotin, $540 \mathrm{mg}$ cholin chloride, $1500 \mathrm{mg} \mathrm{Na}, 120 \mathrm{mg} \mathrm{Zn}, 45 \mathrm{mg} \mathrm{Mn}, 18$ $\mathrm{mg} \mathrm{Cu}, 105 \mathrm{mg} \mathrm{Fe}, 0.36 \mathrm{mg} \mathrm{Co}, 1.8 \mathrm{mg} \mathrm{J}, 0.35 \mathrm{mg} \mathrm{Se}$, $99.9 \mathrm{mg}$ phytase (5000 FTU/g)

${ }^{2 /}$ Calculated from Polish Norm of Pig Nutrition (1993) for comparison. Semen was collected from the boars with the "gloved hand" technique using a phantom.

\section{Semen evaluation}

The following variables were determined immediately on the collection of an ejaculate: total volume, sperm-rich fraction volume, percentage of progressive motility sperm, sperm concentration in $1 \mathrm{~cm}^{3}$ (cytometric method using Bürker's chamber), and the total number of spermatozoa. Prepared slides allowed us to observe major and minor morphological changes of spermatozoa (Blom 1981) as well as acrosome damages (Pursel et al. 1972). Seminal plasma centrifuged from the liquid fraction of ejaculates was used to measure the activity of aspartate aminotransferase, AspAT. Until analyses, the plasma was stored at $-20{ }^{\circ} \mathrm{C}$

Chemical assays

Total protein and raw fibre content in the ration was measured with standard methods (AOAC 1990), while amino-acids were assayed using an automatic analyser (Beckman). AspAT activity in seminal plasma was measured with the kinetic method and calculated per $1 \cdot 10^{9}$ of spermatozoa.

Statistical analyses

The means and standard deviation of the means (SD) were calculated for the studied traits of the boar semen. The resulting numerical data was analysed with one-way ANOVA, significance of differences between the means tested with Duncan range test (Statistica 6.0 PL package).

\section{Results}

The addition of $500 \mathrm{mg}$ of L-carnitine per day for 5 weeks had a positive effect on all the analysed semen quality traits of the boars (Table 2). The activity of AspAT in the seminal plasma of the boar semen decreased by $135 \mathrm{mU} / 10^{9}$ sperm 
$(P<0.01)$. L-carnitine also had a significantly positive effect in terms of both major and minor morphological changes of spermatozoa $(P<0.01)$ as well as the total number of spermatozoa per ejaculate $(P<0.05)$. The total ejaculate volume and sperm-rich semen fraction volume increased by $11 \%$ and $10 \%$, respectively, when the boars received L-carnitine; the differences were, however, statistically non-significant. As far as the remaining traits are concerned, a slight increase was recorded in their values during the period of L-carnitine application. Normal acrosome sperm percentage in the ejaculates collected before and during L-carnitine application remained at a similar, high level $(94.5 \%$ and $95.8 \%$, respectively).

Table 2. Semen characteristics of boars, before and after dietary ( $\bar{x}$ of 5 weeks) L-carnitine

\begin{tabular}{|c|c|c|c|c|}
\hline \multirow[t]{2}{*}{ Item } & $\begin{array}{c}\text { Before dietary } \\
\text { L-carnitine }\end{array}$ & $\begin{array}{l}\text { Standard } \\
\text { deviation }\end{array}$ & $\begin{array}{l}\text { After dietary } \\
\text { L-carnitine }\end{array}$ & $\begin{array}{l}\text { Standard } \\
\text { deviation }\end{array}$ \\
\hline & $\bar{x}$ & SD & $\bar{x}$ & SD \\
\hline Number of evaluated ejaculates & \multicolumn{2}{|c|}{10} & \multicolumn{2}{|c|}{25} \\
\hline Total ejaculate volume $\left(\mathrm{cm}^{3}\right)$ & 338 & 66.5 & 379 & 71.7 \\
\hline Sperm-rich fraction $\left(\mathrm{cm}^{3}\right)$ & 310 & 64.2 & 345 & 67.8 \\
\hline Concentration of spermatozoa $\left(\mathrm{n} \times 10^{6} / \mathrm{cm}^{3}\right)$ & 212 & 60.4 & 220 & 66.2 \\
\hline Total number of spermatozoa $\left(\mathrm{n} \times 10^{9}\right)$ & 65.4 & 17.8 & $73.9^{*}$ & 24.2 \\
\hline Motile spermatozoa (\%) & 70.0 & 6.2 & 72.4 & 5.0 \\
\hline Spermatozoa with major morphological changes (\%) & 18.6 & 8.9 & $12.7^{* *}$ & 7.8 \\
\hline Spermatozoa with minor morphological changes (\%) & 24.6 & 14.2 & $14.5^{* *}$ & 6.9 \\
\hline Spermatozoa with normal acrosome (\%) & 94.5 & 3.1 & 95.8 & 2.6 \\
\hline AspAT (mU/10 spermatozoa) & 349 & 165.2 & $214^{* *}$ & 118.6 \\
\hline
\end{tabular}

Statistical significance $* P<0.05 ; * * P<0.01$

The data presented in Figs 1 - 5 show that the values of the boar semen quality traits increased as early as after one week of L-carnitine supplementation. The volume of both the total ejaculate and its sperm-rich fraction of the boars that had been receiving the supplement for one week increased from 338 to $358 \mathrm{~cm}^{3}$ and from 310 to $320 \mathrm{~cm}^{3}$, respectively (Fig. 1). The highest $(19 \%)$ statistically significant $(P<0.05)$ growth of these traits was noted after four weeks of the experiment. Sperm concentration was by $12-13 \%$ higher during the first two weeks, however, its level returned to the initial value in the remaining periods of L-carnitine administration (Fig. 2). The total number of spermatozoa per ejaculate (Fig. 3) increased by approximately $12 \%(P<0.05)$ in the first week of the experiment, to reach its peak, i.e. $14 \%(P<0.05)$, after 4 weeks. The data presented in Figs 4 and 5 demonstrate that the percentage of sperm with major and minor morphological changes decreased significantly $(P<0.01)$ from $18.6 \%$ to $11.8 \%$ and from $24.6 \%$ to $15.3 \%$, respectively, as early as after one week of L-carnitine-supplemented feeding. Also, seminal plasma AspAT activity decreased (from 349 to $214 \mathrm{mU} / 10^{9}$ sperm).

\section{Discussion}

The results of our experiment have demonstrated a positive effect of L-carnitine on the spermatogenesis of the boars. During the initial two weeks of L-carnitine supplementation to the boars' ration, an increase in the ejaculate sperm concentration was found. On the other hand, reduced concentration observed over the subsequent weeks of the feeding experiment can be explained with a significant increase in the volume of the sperm-rich fraction of semen. In consequence, the total number of spermatozoa per ejaculate was considerably higher during L-carnitine-supplemented feeding compared with the previous 


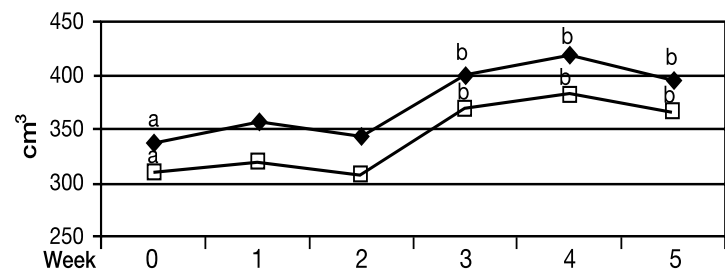

Fig. 1. Ejaculate volume and ejaculate volume after filtration $\left(\mathrm{cm}^{3}\right)$ of boars receiving diet supplemented with $500 \mathrm{mg}$ L-carnitine per day for 5 weeks; statistical significance of the difference between weeks marked $\mathrm{a}, \mathrm{b}-P<0.05$ and $\mathrm{A}, \mathrm{B}-P<0.01$

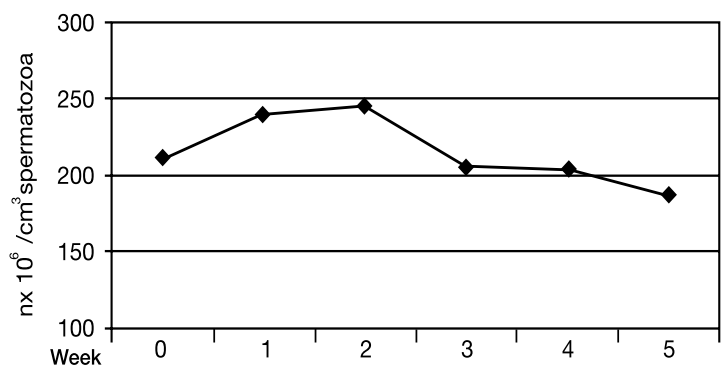

Fig. 2. Concentration of spermatozoa $\left(\mathrm{n} \times 10^{6} / \mathrm{cm}^{3}\right)$ of boars receiving diet supplemented with $500 \mathrm{mg}$ L-carnitine per day for 5 weeks

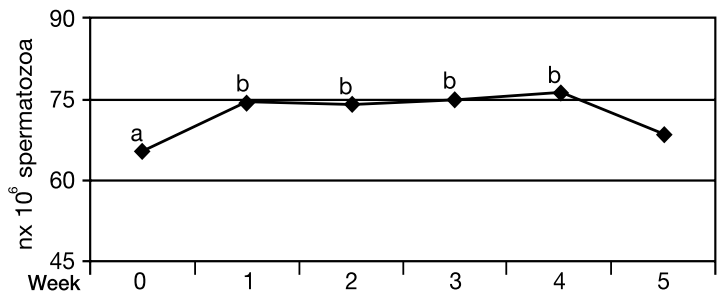

Fig.3. Total number of spermatozoa $\left(\mathrm{n} \times 10^{9}\right)$ of boars receiving diet supplemented with $500 \mathrm{mg}$ L-carnitine per day for 5 weeks; statistical significance of the difference between weeks marked $\mathrm{a}, \mathrm{b}-P<0.05$

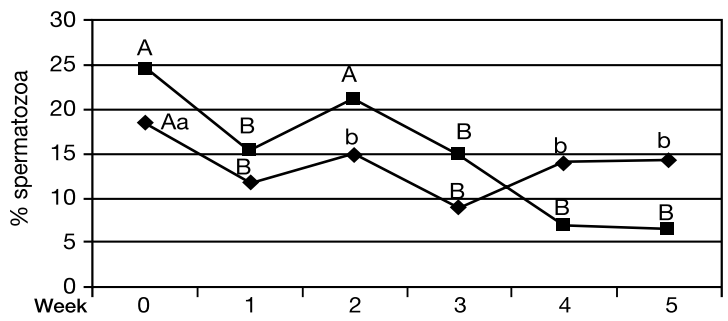

Fig. 4. Spermatozoa with major and minor morphological changes $(\%)$ of boars receiving diet supplemented with 500 mg L-carnitine per day for 5 weeks; statistical significance of the difference between weeks marked a, $\mathrm{b}-P<0.05$ and A,B $P<0.01$ period. Increased volume of the ejaculates and a higher sperm count in the ejaculate of boars receiving $230 \mathrm{mg}$ of L-carnitine per day for 6 weeks were also reported by Währner et al. (2004). Increased ejaculate volume and more sperm cells have important practical consequences for artificial insemination.

An increased sperm count in the ejaculates is probably not due to L-carnitine boosting the spermatogenesis, butitresults from the fact that the supplement contributes to increased survival of spermatozoa in the epididymis. L-carnitine takes part in mitochondrial acetylCoA conversion to acetylcarnitine, which prevents accumulation of acetyl groups that inhibit the activity of pyruvate dehydrogenase responsible for mitochondrial energy metabolism (Rebouche and Seim 1998). This function of L-carnitine enhances sperm survivability and, as a consequence, increases the total number of sperm cells in the ejaculate (Jeulin and Lewin 1996). Kozink et al. (2004) have not observed total spermatozoa to increase in the ejaculates of young boars that received $500 \mathrm{mg}$ of L-carnitine per day. However, the authors have observed significant increasing of spermatozoa concentration already after one week of addition of L-carnitine and continued for the majority of the 16-week study.

Acetylcarnitine is a source of energy needed by sperm cells for their progressive movement (Jeulin and Lewin 1996). A positive effect of L-carnitine on sperm motility was found in men (Vitali et al. 1995; Matalliotakis and Koumantakis 2000) and rats (Palmero et al. 1990). Our experiment has demonstrated that the administration of $500 \mathrm{mg}$ of L-carnitine per day for 5 weeks only slightly increased the percentage of motile sperm. Similar results 


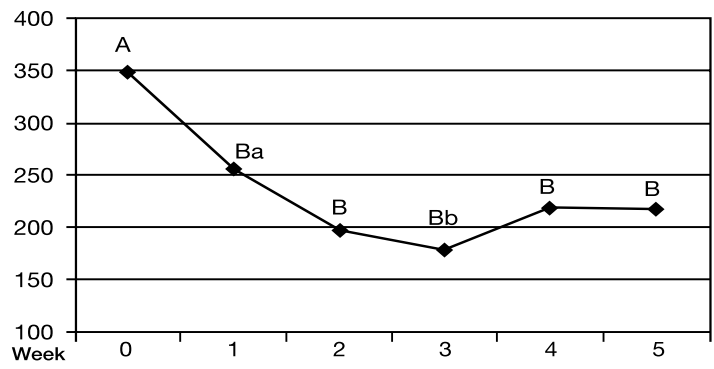

Fig. 5. AspAT activity in seminal plasma (mU/10 $10^{9}$ spermatozoa) of boars receiving diet supplemented with $500 \mathrm{mg}$ L-carnitine per day for 5 weeks; statistical significance of the difference between weeks marked $\mathrm{a}, \mathrm{b}-P<0.05$ and $\mathrm{A}, \mathrm{B}-P<0.01$. The control ejaculates had been collected before the application of L-carnitine (week 0) have been reported by Kozink et al. (2004).

Morphological examination of sperm aimed at determining both qualitative and quantitative changes is one of the most fundamental and unbiased methods of semen quality evaluation. The results of sperm evaluation we conducted have shown that L-carnitine added to the diet significantly prevented both major and minor morphological abnormalities of the sperm.

Aspartateaminotransferase (AspAT) is permanently bound with the basal body of the sperm cell, especially with the mitochondrial membrane.

Increased leakage of AspAT from the sperm cells to the seminal plasma is a symptom of damage in the structure of the sperm cell membrane, but it can also imply reduced activity of this enzyme in the cells. This leads to deteriorated biological value of the sperm.

We have observed significantly lower seminal plasma AspAT activity of the boars receiving L-carnitine, which suggests that administration of this active substance efficiently prevented sperm-cell membrane damages. This is probably a result of the anti-oxidative effect of L-carnitine. Its protective function against the destructive oxygen forms and their derivatives resulting from peroxidation of cellular membrane lipids was observed by other authors (Inoue et al. 2003).

A strong negative relationship between AspAT activity and boar fertility (Ciereszko et al. 1990) allows us to conclude that L-carnitine enhances the fertilising capacity of boar semen.

In summary, the addition of $500 \mathrm{mg}$ L-carnitine per day to boars' ration had a positive effect on their semen quality, especially on the total ejaculate volume, total number of spermatozoa per ejaculate, morphological abnormalities of the sperm, and activity of aspartate aminotransferase.

\section{Vliv př́́davku L-karnitinu na kvalitu semene kanců}

U pěti kanců plemene Piétrain ve věku 1,5 až 2,0 let byl studován účinek př́idavku L-karnitinu na kvalitu jejich semene. Kancům bylo po 5 týdnů denně podáváno $500 \mathrm{mg}$ L-karnitinu. Během této doby byly jednou týdně odebírány ejakuláty a testována jejich kvalita. Kontrolní ejakuláty byly odebrány před podáváním L-karnitinu. Bylo zjištěno, že přidávání L-karnitinu do krmiva kanců mělo pozitivní vliv na kvalitu semene. Celkový objem ejakulátu a druhá-spermiová frakce se zvětšily o $11 \%$ a $10 \%$, celkový počet spermií v ejakulátu vzrostl o $11,5 \%(P<0,05)$. Stejně tak klesl počet spermií s primárními a sekundárními morfologickými vadami a aktivita semenné plasmy (aktivita AspAT) bylo signifikantně redukována $(P<0,01)$. Koncentrace a motilita spermií, stejně jako procento spermií s normálním akrosomem se významně nezvýšily. Pozitivní účinky L-karnitinu na kvalitu semene kanců byly zjištěny již po týdnu aplikace.

\section{References}

AOAC 1990: Official methods of analysis. Association of Official Analytical Chemists. Inc., Arlington, Virginia, $1141 \mathrm{p}$.

ARRIGONI-MARTELLI E, CASO V 2001: Carnitine protects mitochondria and removes toxic acyls from xenobiotics. Drug Exp Clin Res 27: 27-49

BAUMGARTNER M 1998: Boars react positively to L-carnitine supplements. Int Pig Top 13: 22 
BLOM E 1981: Studies on seminal vesiculitis in the bull. II. Proposal for a new classification of the spermiogram. Med Wet 4: 239-242

CIERESZKO A, JABLONOWSKA C, STRZEŻEK J 1990: Aspartate aminotransferase activity in motile and immotile spermatozoa fractions of frozen - thawed boar semen obtained after filtration on columns filled with chitin. Anim Reprod Sci 23: 237-244

HOPPEL C 2003: The role of carnitine in normal and altered fatty acid metabolism. Am J Kidney Dis 41(Suppl.4): S4-12

INOUE M, SATO EF, NISHIKAWA M, PARK AM, KIRA Y, IMADA I, UTSUMI K 2003: Mitochondrial generation of reactive oxygen species and its role in aerobic life. Curr Med Chem 10: 2495-2505

JEULIN C, DACHEUX JL, SOUFIR JC 1994: Uptake and release of free L-carnitine by boar epididymal spermatozoa in vitro and subssequent acetylation rate. J Reprod Fertil 100: 263-271

JEULIN C, LEWIN LM 1996: Role of free L-carnitine and acetyl-L-carnitine in post-gonadal maturation of mammalian spermatozoa. Hum Reprod Update 2: 87-102

JEULIN C, SOUFIR JC, MARSON J, PAQUIGNON M, DACHEUX JL 1987: The distribution of carnitine and acetylcarnitine in the epididymis and epididymal spermatozoa of the boar. J Reprod Fertil 79: 523-529

KALAISELVI CJ, PANNEERSELVAM C 1998: Effect of L-carnitine on the status of lipid peroxidation and antioxidants in ageing rats. J Nutr Biochem 9: 575-581

KOZINK DM, ESTIENNE MJ, HARPER AF, KNIGHT JW 2004: Effects of dietary L-carnitine supplementation on semen characteristics in boars. Theriogenology 61: 1247-1258

MATALLIOTAKIS I, KOUMANTAKIS E 2000: L-carnitine levels in the seminal plasma of fertile and infertile men: correlation with sperm quality. Int J Fertil Womens Med 45: 236-240

NEUMAN SL, LIN TL, HESTER PY 2002: The effect of dietary carnitine on semen traits of White Leghorn roosters. Poultry Sci 81: 495-503

PALMERO S, LEONE M, PRATI M, COSTA M, MESSENI LEONE M, FUGASSA E, DE CECCO L 1990: The effect of L-acetylcarnitine on some reproductive functions in the oligoasthenospermic rat. Horm Metab Res 22: 622-626

PURSEL VG, JOHNSON LA, RAMPACEK GB 1972: Acrosome morphology of boar spermatozoa incubated before cold shock. J Anim Sci 34: 278-283

RAMSAY RR, GANDOUR RD, VAN DER LEIJ FR 2001: Molecular enzymology of carnitine transfer and transport. Biochem Biophys Acta 1546: 21-43

REBOUCHE CJ, SEIM H 1998: Carnitine metabolism and its regulation in microorganisms and mammals. Annu Rev Nutr 18: 39-61

SZILAGYI M 1998: L-carnitine as essential methylated compound in animal metabolism. Acta Biol Hung 49: 209-218

VAZ FM, WANDERS RJ 2002: Carnitine biosynthesis in mammals. Biochem J 361: 417-429

VITALI G, PARENTE R, MELOTTI C 1995: Carnitine supplementation in human idiopathic asthenospermia: clinical results. Drug Exp Clin Res 21: 157-159

WÄHRNER M, GEYER M, HALLFARTH G, HÜHN U 2004: Der Einfluss von Zulagen einer Vitaminemulsion mit L-Carnitin auf die Spermaeigenschaften von Besamungsebern. Zuchtungskunde 76: 196-207 